\title{
Estimated food consumption and feeding effect with different host plants on the development and reproductive capacity of Spodoptera littoralis (boisd.) (lepidoptera: noctuidae)
}

\author{
Al-Shannaf, H. M. H. \\ Plant Protection Research Institute, Agric. Res. Center, Dokki, Giza, Egypt
}

\begin{abstract}
Studies on effect of thirteen host plants on food consumption and some biological aspects for larvae of the cotton leafworm, Spodoptera littoralis (Boisd.) were carried out under laboratory conditions. The results revealed that, the highest means of larval consumption were $0.355,0.353 \mathrm{gm}$ obtained from larva fed on tomato leaves daily, followed by $0.34,0.37$ gm on lettuce daily, while the lowest means were $0.086,0.089 \mathrm{gm}$ of radish. The highest total consumption per larva of $S$. littoralis were 6.13 and $6.20 \mathrm{gm}$, when larvae fed on tomato leaves, while the lowest total consumption per larva were 1.43 and $1.15 \mathrm{gm}$, when larvae were fed on radish, in the two generations, respectively. On the other hand, larvae that fed on turnip leaves had the shortest larval duration $12.64 \& 13.0$ days, while those fed on zorbeyhh leaves had the longest one $20.89 \& 21.62$ days, in the two generations, respectively. In the case of pupae, the heaviest pupa $(0.44 \& 0.44 \mathrm{gm})$ was obtained from larvae fed on castor bean oil leaves. However, the lightest pupa $(0.14 \& 0.16 \mathrm{~g})$ was obtained from larvae fed on Radish and zorbeyhh leaves, respectively in both generations. In the case of the moth, longevity was also affected by larval food. Males and Females emerging from larvae fed on tomato leaves had the longest life span $11.78 \& 11.11$ days, respectively; while males resulting from larvae fed on zorbeyhh leaves or cabbage showed the shortest life span (5.89 \& 5.95 days), but females produced from larvae fed on purslane or pepper leaves had the shortest life span (5.17 \& 5.56 days) in the first generation. While males produced from larvae fed on pepper leaves or cabbage showed the shortest life span ( $6.22 \& 6.42$ days); purslane or cabbage leaves had the shortest life span ( $5.42 \& 5.56$ days) in the second generation. Female moths produced from larvae fed on castor bean oil leaves laid the highest number of eggs $2171 \& 2139$ eggs; but zorbeyhh produced the least number, $733.3 \& 766.9$ eggs, in the two generations, respectively.
\end{abstract}

Keywords: Spodoptera littoralis, food consumption, REPRODUCTIVE CAPACITY

\section{INTRODUCTION}

The cotton leafworm, Spodoptera littoralis (Boisd.) has been considered as serious economic pest of cotton and various vegetable and field crops all over the year in Egypt (Laila and Dahi 2008 and Fatma et al., 2009). The effect of larval diet on the biology of this pest has been studied by many authors (Basu, 1943; Nasr and Ibrahim, 1965; Badr, 1967 and Patel et al., 1968. Also, Moufied et al., (1960) mentioned that, approximately112 plant species belonging to 44 families are reported as hosts of the cotton leafworm in tropical; and temperate zones of the old world. These plants include 73 species recorded from Egypt.

Most insects have qualitatively similar nutritional requirements since the basic chemical composition of their tissues and their metabolic processes are 
generally similar. Most of these requirements are normally met by the diet. Some chemicals can only be obtained in the diet, they are essential. Others may by synthesized by the insect from dietary components (Chapman, 2002). Consequently, several authors namely (Badr, 1982; Risk et al. 1988; Mohamed, 2003 and Adham, et al. 2009) contributed to the biology of $S$. littoralis and the effect of different host plants on its development and reproductive capacity

This study aims to determine cotton leafworm larval consumption rates on thirteen common host plants, effects of consumption rate on pupal weights and effect of feeding various foods on some biological aspects of $S$. littoralis.

\section{MATERIALS AND METHODS}

Host plants: Thirteen different host plants were used i.e. leaves of castor oil (Ricinus commumis); Radish(Raphanus sativus); lettuce (Lactuce sativa); eggplant (Solanum melongena); tomato (Lycopersicum esculeatum );zorbeyhh (Chenopodium album); okra (Hibiscus esculentus); cabbage (Brassica oleracea); purslane (Portulaca oleraceae); turnip (Brassica campostris var. rapa); pepper (Cafsicum annum); mulberry (Morus sp.); and siris (Cichorium pumilum).

Choice of hosts was based on the fact that, some of hosts are heavily attacked in fields while the other are preferred for oviposition (Moufied et al., 1960).

\section{Test insects:}

Cotton leafworm larvae were obtained from batches of eggs collected from neighboring fields. Larvae were reared for one generation on the same host plants on which the following generation was evaluated except for the two hosts (mulberry and siris). Larvae from the next generation were used for tests.A mean temperature of 26 $\pm 1{ }^{\circ} \mathrm{C}$ and average R.H. of $70 \pm 5 \%$ were recorded during the course of the present study.

\section{Feeding tests:}

Larval feeding on the thirteen different host plants was tested. Thirty newly hatched larvae per each treatment divided into three replicates were isolated in separate 2-pound glass jars, covered with muslins. Larvae of each replicate were daily provided with fresh weighed leaves of one of the preceding host plants. After $24 \mathrm{~h}$ the remaining leaf tissues were removed, then weighed. Jars were cleaned and new weighed leaves were supplied. This process was contained every day for each replicate until feeding ceased in prepupa.

To determine lost weight caused by evaporation, leaves of known weight were exposed to the same conditions for a similar period without larvae and weighed thereafter (control). Daily food consumption per larva was estimated by subtracting weight of remaining leaf tissue from weight of leaf provided and correcting for evaporation. Records of the durations of the larval and pupal stages were taken. The resulting pupae were weighed singly 24 hours after pupation. They were then kept each in a separate vial till the moths emerged. Three pairs of newly emerged moths were isolated in glass jars (three pairs / replicate) and were offered sugar solution at the concentration of $10 \%$ as food. Each jar was supplied with a small branch of Nerium oleander to act as a suitable site for oviposition. Daily counts of eggs laid were made till moths died. Jars were examined daily to record female mortality, pre oviposition period and number of eggs laid (fecundity). 


\section{Statistical analysis:}

The effect of host plant on larval consumption rate using one-way analysis of variance (ANOVA). Means associated with host plant for each variable were separated using the (L.S.D.) test when significant $F$ values were obtained by Little and Hills (1975). For each type of host plant simple coefficient of correlation was used to examine the relationship between the amount of diet consumed and larval duration and pupal weight.

\section{RESULTS AND DISCUSSION}

\section{Consumption of eleven different host plants by larvae of $S$. littoralis:}

1. Mean weight of leaf tissue consumed per larva:

The highest mean larval consumption was $(0.355,0.353 \mathrm{gm})$ and $(0.34,0.37$ gm) of tomato and lettuce daily, respectively, while the lowest mean larval consumption was $(0.086,0.0899 \mathrm{gm})$ of radish daily, $(0.11,0.129 \mathrm{gm})$ of zorbeyhh daily in the two generations, respectively (Fig.1 A).

\section{Total weight of leaf tissue consumed per larva for each host plant}

Total consumptions per S. littoralis larva were highest in tomato $(6.13 \mathrm{gm})$, egg plant (5.98 gm), purslane (5.91 gm) and pepper (5.29 gm) and lowest in radish $(1.43 \mathrm{gm})$ in the first generation.

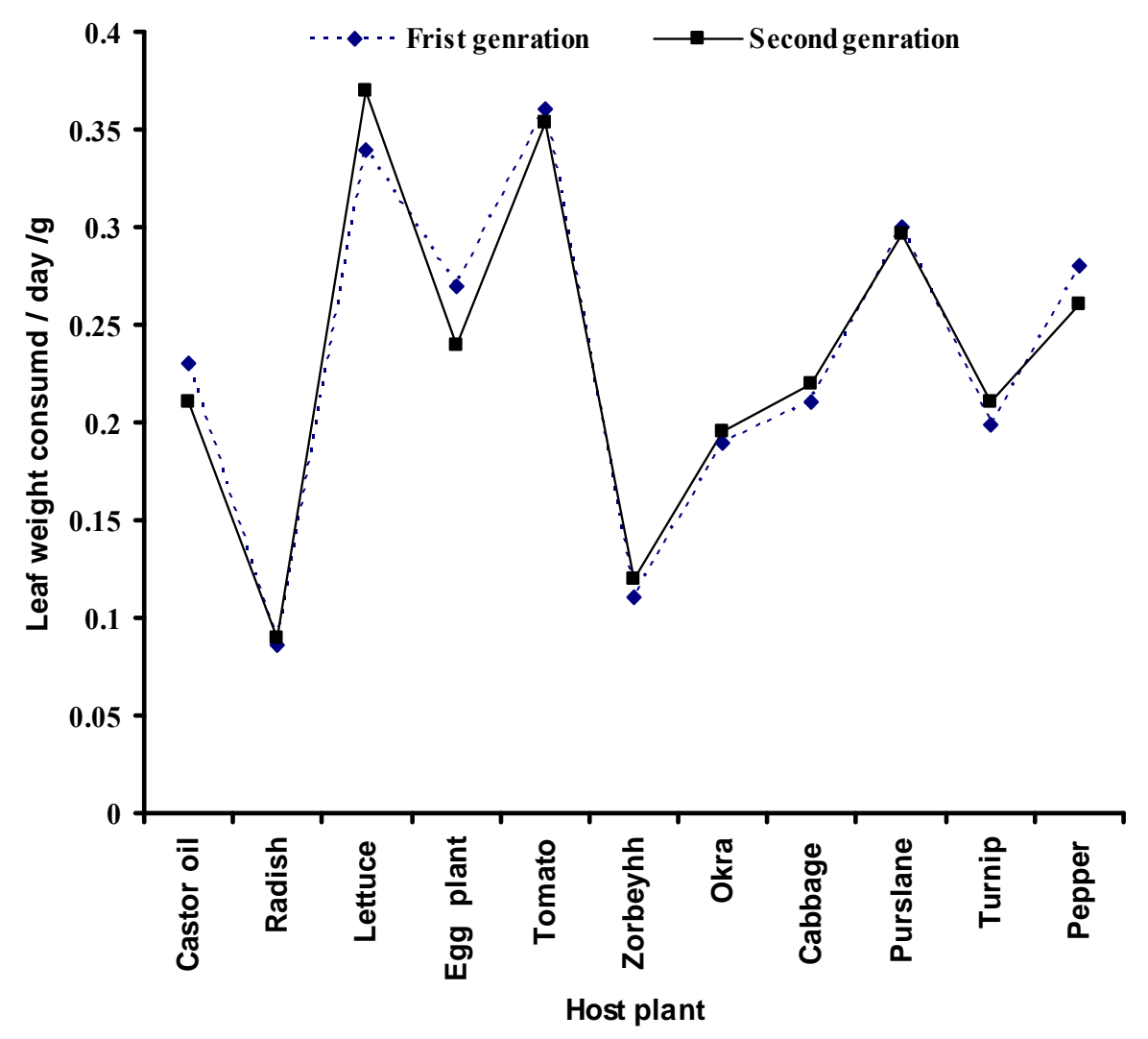

$\pm=$ Stander Division

G1 $\mathrm{LSD} 0.05=0.67$

G2 LSD0.05 $=0.44$

Fig (1): Consumption of eleven different host plants by larvae of S. littoralis (bars indicate SD). (A) Mean weight of leaf tissue consumed / day/gram. 
However, the total consumptions per larva were highest in tomato (6.2 gm), purslane $(6.02 \mathrm{gm})$, lettuee $(5.23 \mathrm{gm})$ and pepper $(5.07 \mathrm{gm})$ in the second generation, while the lowest total consumption was $(1.51 \mathrm{gm})$ in radish in the second generation . (Fig.1B). However, intermediate total consumption was obtained for the remaining host plants in the two generations.

On all host plants, positive correlations were found between amounts of leaf tissue consumed during the duration of the larval stage $(0.24,0.20 \mathrm{gm}$. $)$ in the two generations, respectively. However, significant relationships were found between amount of leaf tissue consumed and resulting pupal weight Greenberg et al. (2001), Gupta and Thorstcinson (1960); Yamamoto and Fraenkel (1960); Hsiao and Fraenkel 1968. Also, Mitchell and Heath (1985) revealed that, there is evidence of substances in pigweed that can deter beet armyworm feeding.

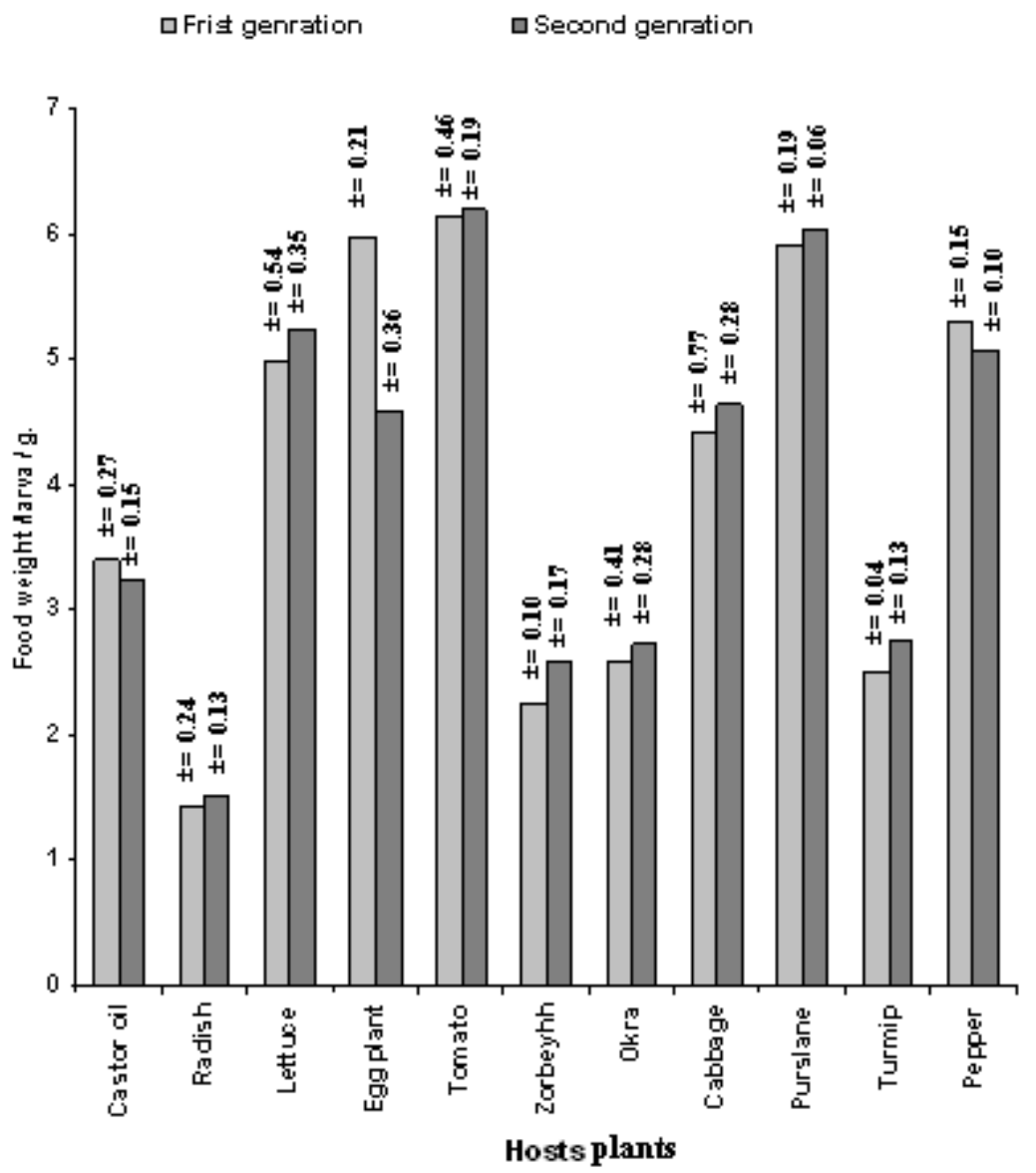

$\pm=$ Stander Division

G1 $\mathrm{LSD} 0.05=0.67$

G2 LSD0.05 $=0.44$

Fig. 1: (B) Total weight of leaf tissue consumed /larva for each host plant.

\section{Duration of the larval stage}

Host plants have variable effects on development of larvae of the cotton leafworm, S. littoralis. The data recorded in Tables (1\&2) show that the duration of the larval stage is affected by the different host plants offered. In the first generation, the shortest mean duration 12.64, 13.63 and 14.61 days were recorded for larvae fed on 
turnip, okra and lettuce, respectively. The same results were recorded in the second generation where, the shortest mean duration 13.0, 13.95 and 14.32 days were recorded for the same host plants. On the contrary, the longest period for larval development $(20.89,20.67,19.56$ and 19.16 days) resulted when larvae were offered zorbeyhh, cabbage, purslane and Pepper, respectively in the first generation (Table 1). Also, the same results were obtained in the second generation (Table 2) where, the longest mean duration were $(21.62,21.31,20.29$ and 19.59 days) at the above mentioned same host plants. However, intermediate means were obtained for the remaining host plants in the two generations.

Table1: Effect of host plants on some biological aspects of the first generation for the cotton leafworm, S. littoralis.

\begin{tabular}{|c|c|c|c|c|c|c|c|}
\hline \multirow[b]{2}{*}{ Host plant } & \multicolumn{3}{|c|}{ Duration of stages (days) } & \multirow{2}{*}{$\begin{array}{c}\text { Weight of } \\
\text { pupae (gm) }\end{array}$} & \multicolumn{2}{|c|}{ Longevity (days) } & \multirow[b]{2}{*}{ Mean No. of eggs } \\
\hline & $\begin{array}{c}\text { Larval } \\
\text { mean } \pm \text { SD }\end{array}$ & $\begin{array}{c}\text { Pre-pupa } \\
\text { mean } \pm \text { SD }\end{array}$ & \begin{tabular}{|c|} 
Pupal mean \\
\pm SD
\end{tabular} & & $\begin{array}{l}\text { Male mean } \\
\quad \pm \text { SD }\end{array}$ & $\begin{array}{c}\text { Female } \\
\text { mean } \pm \text { SD }\end{array}$ & \\
\hline Castor oil & $15.04 \pm 0.13$ & $1.00 \pm 0.00$ & $8.67 \pm 0.27$ & $0.44 \pm 0.018$ & $8.33 \pm 0.24$ & $8.03 \pm 0.45$ & $2171.8 \pm 117.5$ \\
\hline Radish & $16.56 \pm 0.42$ & $1.02 \pm 0.01$ & $7.03 \pm 0.05$ & $0.14 \pm 0.002$ & $8.0 \pm 0.27$ & $8.94 \pm 0.34$ & $1391.7 \pm 31.2$ \\
\hline Lettuce & $14.61 \pm 0.08$ & $1.00 \pm 0.00$ & $7.00 \pm 0.00$ & $0.29 \pm 0.004$ & $7.72 \pm 0.21$ & $10.11 \pm 0.16$ & $1755.6 \pm 67.0$ \\
\hline Egg plant & $18.55 \pm 0.32$ & $1.03 \pm 0.005$ & $9.33 \pm 0.27$ & $0.22 \pm 0.005$ & $7.89 \pm 0.16$ & $7.44 \pm 0.42$ & 53.1 \\
\hline Tomato & $17.28 \pm 0.25$ & $1.00 \pm 0.00$ & $10.82 \pm 0.14$ & $0.26 \pm 0.001$ & $11.78 \pm 0.32$ & $11.11 \pm 0.16$ & 44.4 \\
\hline Zorbeyhh & $20.89 \pm 0.16$ & $1.00 \pm 0.00$ & $8.11 \pm 0.16$ & $0.16 \pm 0.001$ & $5.89 \pm 0.16$ & $7.33 \pm 0.27$ & $733.3 \pm 26.3$ \\
\hline Okra & $13.63 \pm 0.21$ & $1.00 \pm 0.00$ & $7.11 \pm 0.16$ & $0.20 \pm 0.006$ & $7.72 \pm 0.21$ & $9.06 \pm 0.20$ & $1818.5 \pm 16.5$ \\
\hline Cabbage & $20.67 \pm 0.27$ & $1.00 \pm 0.00$ & $9.33 \pm 0.27$ & $0.24 \pm 0.006$ & $5.95 \pm 0.21$ & $5.67 \pm 0.0$ & $927.6 \pm 14.2$ \\
\hline Purslane & $19.56 \pm 0.42$ & $1.00 \pm 0.00$ & $8.82 \pm 0.14$ & $0.18 \pm 0.006$ & $10.97 \pm 0.05$ & $5.17 \pm 0.15$ & $898.7 \pm 11.7$ \\
\hline Turnip & $12.64 \pm 0.74$ & $1.00 \pm 0.00$ & $7.33 \pm 0.27$ & $0.24 \pm 0.009$ & $9.25 \pm 0.09$ & $8.03 \pm 0.05$ & $1973.6 \pm 79.6$ \\
\hline Pepper & $19.16 \pm 0.48$ & $1.00 \pm 0.00$ & $9.33 \pm 0.27$ & $0.26 \pm 0.002$ & $6.0 \pm 0.00$ & $5.56 \pm 0.42$ & $790.6 \pm 14.6$ \\
\hline Mulbeary * & - & - & - & - & - & - & - \\
\hline Siris * & - & - & - & - & - & - & - \\
\hline F. test & $* *$ & $* *$ & $* *$ & $* *$ & $* *$ & $* *$ & $* *$ \\
\hline LSD 0.05 & 0.75 & 0.008 & 0.42 & 0.02 & 0.40 & 0.58 & 144.67 \\
\hline
\end{tabular}

* =Young larvae failed to survive

Table 2: Effect of host plants on some biological aspects of the second generation for the cotton leafworm, S. littoralis.

\begin{tabular}{|c|c|c|c|c|c|c|c|}
\hline \multirow[b]{2}{*}{ Host plant } & \multicolumn{3}{|c|}{ Duration of stages (days) } & \multirow{2}{*}{$\begin{array}{l}\text { Weight of } \\
\text { pupae (gm) }\end{array}$} & \multicolumn{2}{|c|}{ Longevity (days) } & \multirow[b]{2}{*}{$\begin{array}{c}\text { Mean No. of } \\
\text { eggs }\end{array}$} \\
\hline & $\begin{array}{c}\text { Larval mean } \\
\pm \text { SD } \\
\end{array}$ & $\begin{array}{l}\text { Pre-pupa } \\
\text { mean } \pm \text { SD }\end{array}$ & $\begin{array}{c}\text { Pupal } \\
\text { mean } \pm \text { SD }\end{array}$ & & $\begin{array}{c}\text { Male } \\
\text { mean } \pm \text { SD }\end{array}$ & $\begin{array}{c}\text { Female } \\
\text { mean } \pm \text { SD }\end{array}$ & \\
\hline Castor oil & $15.61 \pm 0.21$ & $1.00 \pm 0.00$ & $8.72 \pm 0.21$ & $0.44 \pm .024$ & $8.47 \pm 0.14$ & $8.37 \pm 0.23$ & $2139.6 \pm 51.5$ \\
\hline Radish & $16.86 \pm 0.38$ & $1.00 \pm 0.00$ & $7.00 \pm 0.00$ & $0.14 \pm 0.002$ & $8.38 \pm 0.22$ & $8.56 \pm 0.16$ & $1423.3 \pm 9.8$ \\
\hline Lettuce & $14.32 \pm 0.29$ & $1.00 \pm 0.00$ & $7.00 \pm 0.00$ & $0.29 \pm 0.003$ & $7.81 \pm 0.14$ & $9.88 \pm 0.15$ & $1757.1 \pm 33.3$ \\
\hline Egg plant & $18.89 \pm 0.31$ & $1.02 \pm 0.01$ & $9.56 \pm 0.16$ & $0.22 \pm 0.006$ & $7.84 \pm 0.14$ & $7.62 \pm 0.22$ & $1260.2 \pm 26.7$ \\
\hline Tomato & $17.56 \pm 0.16$ & $1.00 \pm 0.00$ & $10.82 \pm 0.11$ & $0.25 \pm 0.004$ & $11.89 \pm 0.16$ & $11.33 \pm 0.27$ & $1272.0 \pm 38.0$ \\
\hline Zorbeyhh & $21.62 \pm 0.22$ & $1.00 \pm 0.00$ & $8.15 \pm 0.14$ & $0.16 \pm 0.002$ & $6.33 \pm 0.27$ & $7.56 \pm 0.16$ & $766.9 \pm 45.1$ \\
\hline Okra & $13.95 \pm 0.28$ & $1.00 \pm 0.00$ & $7.00 \pm 0.00$ & $0.27 \pm 0.004$ & $7.39 \pm 0.21$ & $9.39 \pm 0.21$ & $1889.0 \pm 8.1$ \\
\hline Cabbage & $21.31 \pm 0.30$ & $1.00 \pm 0.00$ & $9.38 \pm 0.22$ & $0.25 \pm 0.002$ & $6.42 \pm 0.18$ & $5.56 \pm 0.16$ & $915.2 \pm 15.1$ \\
\hline Purslane & $20.29 \pm 0.33$ & $1.00 \pm 0.00$ & $8.99 \pm 0.27$ & $0.19 \pm 0.004$ & $10.98 \pm 0.02$ & $5.42 \pm 0.18$ & $82909 \pm 12.3$ \\
\hline Turnip & $13.00 \pm 0.27$ & $1.00 \pm 0.00$ & $7.33 \pm 0.27$ & $0.24 \pm 0.008$ & $9.41 \pm 0.19$ & $8.44 \pm 0.16$ & $1914.2 \pm 30.1$ \\
\hline Pepper & $19.59 \pm 0.26$ & $1.00 \pm 0.00$ & $9.39 \pm 0.21$ & $0.26 \pm 0.005$ & $6.22 \pm 0.16$ & $5.67 \pm 0.28$ & $778.1 \pm 18.9$ \\
\hline Mulbeary * & - & - & - & - & - & - & - \\
\hline Siris * & - & - & - & - & - & - & - \\
\hline F. test & $* *$ & $* *$ & $* *$ & $* *$ & $* *$ & $* *$ & $* *$ \\
\hline LSD 0.05 & 0.58 & 0.005 & 0.36 & 0.02 & 0.36 & 0.42 & 61.74 \\
\hline
\end{tabular}

$*=$ Young larvae failed to survive

The difference between the means proved to be statistically significant (L.S.D. $=$ 0.75 and 0.58 for $1^{\text {st }}$ and $2^{\text {nd }}$ generations. Finally, larvae reared on leaves of mulberry and siris surrendered a heavy mortality rate, where, young larvae failed to survive in 
the two generations. In this respect, Basu (1943) found that the larval duration was shorter in the cabbage than in the cotton one, while Moufied et al. (1960) mentioned that the shortest period of larval stage was obtained from larvae fed upon leaves of castor oil plant and berseem. Also, Badr (1967) found that sweet potato and castor oil tended to shorten the duration of the larval stage. Finally, the shortest mean duration was recorded for larvae fed on beet by El-Sayed et al. (1973). Daimon et al. (2008) found that mulberry latex contains extremely high concentrations of alkaloid sugar mimic glycosidase inhibitors, these compounds do not harm the silkworm, Bombyx mori, but they are highly toxic to insects that do not normally feed on mulberry leaves.

\section{Duration of the pupal stage}

Subsequent effects of host plants have been manifested on pupal development. The shortest durations were 7.0, 7.03, and 7.11 and 7.33 days for pupae obtained from larvae fed on lettuce, radish, okra and turnip, respectively, these plants had equal effects in pupal duration in the first generation (Table 1). Also, the same results were obtained in the second generation (Table 2). The longest mean pupal duration (10.82 days) resulted in the two generations, when larvae fed upon leaves of tomato. However, intermediated means were obtained for the remaining host plants in the two generations. Analysis of variance showed that differences in pupal duration among treatments were highly significant, ( $\mathrm{LSD}=0.42,0.36$ Tables, 1 and 2), respectively. Similar results were also observed when examining data given by Basu (1943), Moufied (1960), Badr (1967) and El-Sayed et al. (1973).

\section{Pre-pupal duration}

Data illustrated in Tables $(1 \& 2)$ revealed that the pre-pupal stage was not greatly affected with the food plants of larvae. The longest pre-pupal duration were 1.03 and 1.02 days for the larvae fed on eggplant leaves, in the two generations, respectively? While, the shortest one was 1.00 day obtained for larvae fed on the remaining host plants in the two generations. The above mentioned result agrees with that obtained by Zaazou et al., (1973).

\section{Effect of host plants on pupal weight:}

Weights of newly formed pupae were influenced by larval food. Pupae developed from larvae fed on castor oil leaves showed the heaviest mean weights in the two generations Tables (1\& 2). The same results were however obtained by Badr (1967), El-Sayed et al., (1973).

Radish and zorbeyhh gave the lightest pupal weights. From the results obtained ,host plants may be arranged into three categories (1)Host plants that produce heavy weight pupa $(0.44 \mathrm{gm})$ as castor oil (2) Host plants producing moderate weight pupa $0.29,0.26,0.26,0.24,0.24,0.22$ and 0.20 gm as lettuce ,tomato ,pepper , turnip ,cabbage ,eggplant and okra ,respectively (Table 1). The same results were obtained in (Table 2). (3) Finally, host plants which produce light pupa $(0.14$, 0.16 and $0.18 \mathrm{gm})$ as radish, zorbeyhh and purslane, respectively. In the present study, the positive correlation between the weight and duration of the pupal stage ( 0.22 and 0.18 ) were observed in the two generations, respectively. However, the negative correlation between the weight and duration of the pupal stage observed by Nasr and Ibrahim (1965). At the same time, the correlation was not observed by El-Sayed et al. (1973).

\section{Longevity of moths:}

The results shown in Tables $(1 \& 2)$ indicated that, the moth longevity was affected by larval food. Males and females emerging from larvae fed on tomato leaves had the longest life span 11.78 and 11.11 days, respectively; while males resulting 
from larvae fed on zorbeyhh or cabbage leaves showed the shortest life span (5.89 and 5.95 days), but females produced from larvae fed on purslane or pepper leaves had the shortest life span (5.17 and 5.56 days) in the first generation. While males produced from larvae fed on pepper leaves or cabbage showed the shortest life span $(6.22$ and 6.42 days); purslane or cabbage leaves had the shortest life span (5.42 and 5.56 days) in the second generation.

\section{Effect of host plants on reproductive capacity:}

Larval food has a marked effect on number of eggs laid by moths. Castor oil leaves proved to be the most favorable host plant for egg production. Moths produced from larvae fed on this host plants laid the highest number of eggs (2171.8 and 2139.6 eggs per female) in the two generations, respectively. The same results were observed by Hosni and Khatbi (1960), El-Sayed et al. (1973), where female moths prefer egg laying on the same host plant. A contradicting result was however obtained by Badr (1967) who stated that females fed as larvae on sweet potato and tomato produced the highest number of eggs. The least numbers of eggs 733.3 and 790.6 eggs/female in the first generation and 765.8 and $778.1 \mathrm{eggs} /$ female in the second generation were laid by females fed as larvae on zorbeyhh and pepper, respectively.

\section{REFERENCES}

Adham Fatma, K.; Rashad Eman, M.; Shoukry, I. F. and Nasr Enas, E. (2009). Host plants shifting affects the biology and biochemistry of Spodoptera littoralis (Bioisd) [Lepidoptera:Noctuidae] J. Biological. Sci. 2 (1): 63-71.

Badr, N.A. (1967). Effect of different host plants on the development and reproduction of the cotton leafworm, Prodenia litura F. M.Sc. Thesis, Alexandria Univ.,

Badr, N.A. (1982). Biological and ecological studies on the cotton leafworm Spodoptera littoralis (Bioisd). Ph.D.Thesis, Fac. Agric., Cairo Univ.

Basu, A.C. (1943). Effect of different foods on the larval and post larval development of the moth of Prodenia litura F. (J. Bombay Nat. Hist. Soc., XLIV (2), pp. 275-288.

Chapman, R. F. (2002). The insects: Structure and function. $4^{\text {th }}$ Edition, Cambridge University press.

Daimon, .T; Taguchi, T.; Meng, y.; Katsuma, S.; Mita, K. and Shimada, T. (2008). Beta fructofuranosidase genes of the silkworm, Bombyx mori, insights into enzymatic adaptation of B.mori to toxic alkaloids in mulberry latex. J. Bio .Chem. (22): 15271-9.

El-Sayed A. N.; El- Rafiei, K.; Hosny. M.M; and Badawi ,A.(1973). Effect of host plants on the biology of the cotton leafworm, Spodoptera littoralis (Boisd.) [Lepidoptera: Noctuidae] Bull. Soc. Ent. Egypt LVII 27:32.

Fatma, K. Adham; Eman, M. Rashad; Ibrahim, F. Shoukry and Enas, E. Nasr (2009). Host plants shifting affects the biology and biochemistry of spodoptera littoralis (boisd.) (lepidoptera: noctuidae).Egypt. Acad. J. Biol. Sci. 2(1):63-71.

Greenberg, S. M.; Sappington, T. W.; Legaspi, B. C.; Liu, T.X.; and Setamou, M.(2001). Feeding and life history of Spodoptera exigua [Lepidoptera:Noctuidae ] on different host plants . Annals of the Entomological Society of America, 94 (4): 566-575.

Gupta, P.D. and Thorsteinson, A. J. (1960). Food plant relationships of the diamondback moth [Plutella maculipennis (Curt.)] II. Sensory regulation of oviposition of the adult female, Entomol. Exp. Appl., 3: 305-314.

Hsiao, T. H. and Fraenkel, G. (1968). Selection and specificity of the Colorado potato beetle for solanaceous and nonsolanaceous plants. Ann. Entomol. Soc. Am. 61: 493-503.

Laila, S. Hamouda and Dahi H. F. (2008). Neurotoxic effect of spinetoram on Spodoptera littoralis (Boisd.) Larvae. Egypt. Acad. J. Biol. Sci., 1(2):27-36.

Little, T.M. and Hills, F. J. (1975). Statistical methods in agricultural research from U. C. D. Book Store, University California, Davis, $241 \mathrm{pp}$. 
Mitchell, E.R., and Heath, R.R. (1985). Influence of Amaranthus hybridus L. Allelochemics on oviposition behavior of Spodoptera exigua and S. Eridania [Lepidoptera: Noctuidae]. J. Chem. Ecol., 11:609-618.

Mohamed, H.H. (2003). Comparative study of host plants on growth, development and fecundity of the cotton leafworm Spodoptera littoralis (Boisd.) [Lepidoptera: Noctuidae]. J. Egypt. Ger. Soc. Zool. 42(E):167-183.

Moufied ,A. M.; Zaher, M.A. and Kotby, Fawkia (1960). Abundance of the cotton leafworm in relation to host plants. Bull. Soc. Entom. Egypte, XLIV pp240-251.

Nasr, E. A. and Ibrahim (1965). Contribution to the biology of the cotton leafworm, Prodenia litura F.with reference to larval coloration .Bull. Soc. Entom. Egypte, XLIX, pp. 159162.

Patel, H.K.; Patel, R.M. and Patel, V.C. (1968). Effect of food and temperature on the durations of various stages of tobacco leaf - eating caterpillar Prodenia litura F. India. Tob., XV(4), pp 174-176.

Rizk, G.A; Hussein , S.M and Hafez, H.F. (1988). Studies on biotic potential of the cotton leafworm Spodoptera littoralis (Boisd.) with special reference to the effect of host plants on larval susceptibility to synthectic pyrethroids. Bull. Ent. Soc. Egypt, Econ. Ser., 17:47-55.

Yamamoto, R.T. and Fraenkel, G. (1960). The physiological basis for the selection of plants for egg-laying in the tobacco hornworm Protoparce sexta (Johan). II Int-Congr. Entomol., 3: 127-133.

Zaazou, M. H.; Hosni, S. M. F.; Kamel, A.A. M; and El- Hemaesy, A.H. (1973): Effect of food on the development of the greasy cutworm, Agrotis ipsilon (Hufn) [Lepidoptera: Noctuidae ]. Bull. Soc. Ent. Egypte LVII pp 379-385.

\section{ARABIC SUMMARY}

\footnotetext{
تقدير استهلاك الغذاء و تأثير التظذية بعوائل نباتية مختلفة على التطور والكفاءة التناسلية لدودة ورق القطن

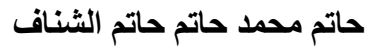

معهد بحوث وقاية النباتاتـ مركز البحوث الزر اعيةــ الدقىـ الجيزة- مصر

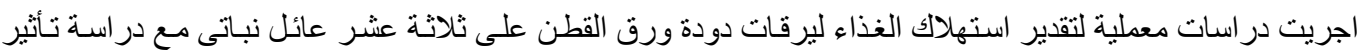

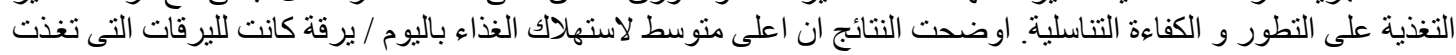

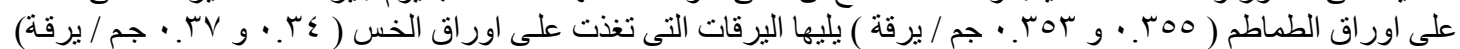

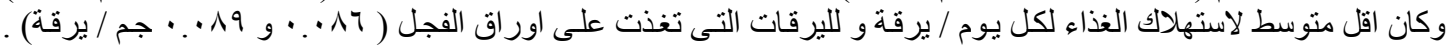

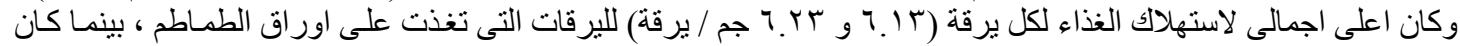

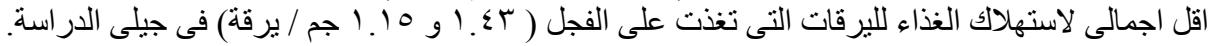

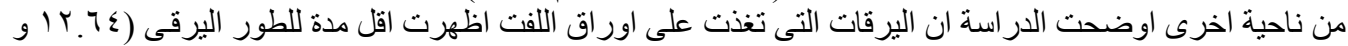

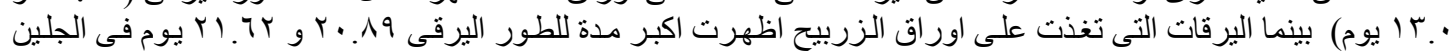

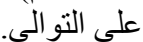

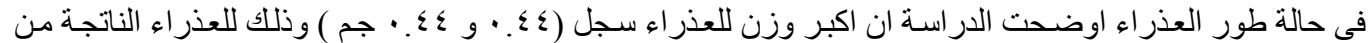

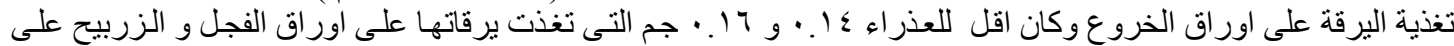

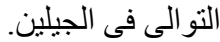

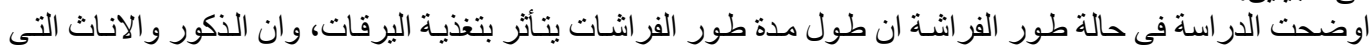

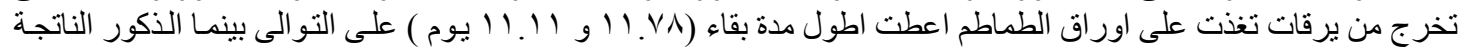

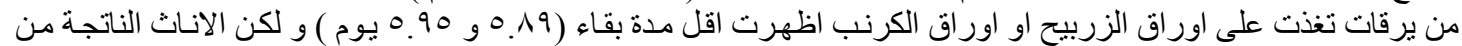

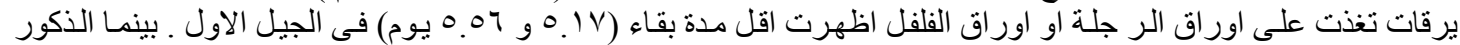

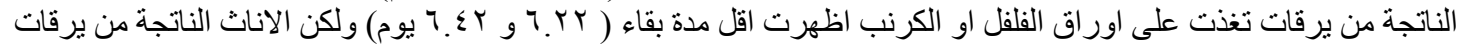

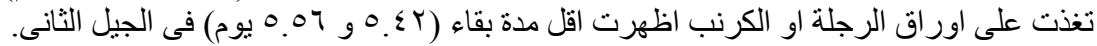

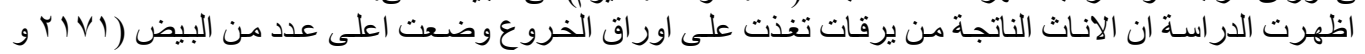

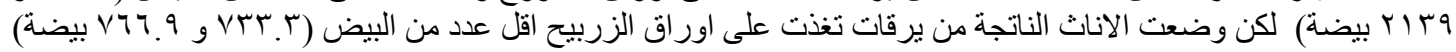

